
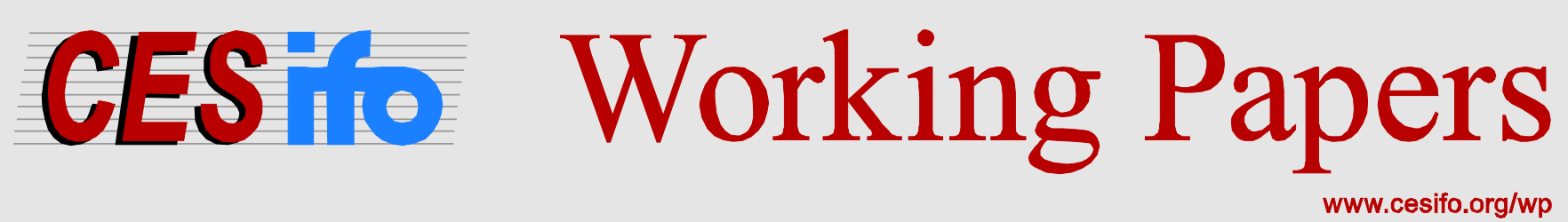

\title{
Chain of Legitimacy: Constitution Making in Iceland
}

\author{
Thorvaldur Gylfason
}

CESIFO WORKING PAPER NO. 6018

CATEgory 2: Public CHOICE

JULY 2016

An electronic version of the paper may be downloaded

- from the SSRN website:

- from the RePEc website:

WWw.SSRN.com

www.RePEc.org

- from the CESifo website:

www.CESifo-group.org/wp 


\title{
Chain of Legitimacy: Constitution Making in Iceland
}

\begin{abstract}
To understand Iceland's political situation, it is necessary to consider the historical background to the post-crash constitutional revision process launched in 2009. Also, the paper offers a brief account of some aspects of the constitution-making process during 2010-2013, including the work of the Constituent Assembly. Further, the paper describes Parliament's ongoing attempt to undermine the substance of the constitutional bill accepted by two thirds of the voters in the 2012 referendum. A national parliament cannot, without undermining its own legitimacy, allow the results of a constitutional referendum to be changed after the fact, let alone ignored, even if the referendum was advisory.
\end{abstract}

JEL-Codes: K100.

Keywords: legitimacy, democracy, constitutions, Iceland.

Thorvaldur Gylfason

Department of Economics

University of Iceland

Iceland - 101 Reykyavik

gylfason@hi.is

\section{July 2016}

Prepared for a conference on "Perspectives on Constituent Assemblies" hosted by the Institute of Religion, Culture and Public Life at Columbia University and the Department of Political Science at the University of Oslo and held at Columbia University in New York 1-2 April 2016. I wish to thank Andrew Arato, David Dyzenhaus, Jon Elster, Roberto Gargarella, Kim Scheppele, Hélène Landemore, Gabriel Negretto, Björn Erik Rasch, other participants at the conference, and also Sigríður Ólafsdóttir for helpful comments and suggestions. 
In a democracy, what does it take to break the chain of political legitimacy? A common answer suggested by political philosophers is that this question must be answered primarily on the basis of procedural features that shape political institutions and underlie the decisions made as well as on the basis of the substantive outcomes realized. ${ }^{1}$ For example, Carlton $(1986,23)$ defines political legitimacy as follows: "In a democracy, government legitimacy derives from the popular perception that the elected government abides by democratic principles in governing, and thus is legally accountable to its people." Jon Elster stated the case clearly ${ }^{2}$ on national television in Iceland 13 May 2012: "If the people approved the constitutional proposal I think Parliament would find it difficult to override the moral authority of the people."

This paper suggests that the Icelandic Parliament, one of the world's oldest (est. 930), is on the verge of violating the normal requirements of political legitimacy, thus jeopardizing Iceland's standing among democratic nations. Iceland's financial system crashed in 2008, leading the people to demand and Parliament to promise a new constitution to be drawn up by representatives directly elected by the people. A constituent assembly was elected and convened according to law. The assembly drafted a new constitution that was accepted by $67 \%$ of the voters in a 2012 national referendum called by Parliament. Then, bolstered by signs that the IMF-orchestrated economic rescue operation financed in part by loans from Danish, Finnish, Norwegian, Polish, and Swedish tax payers was headed for success, Parliament reverted to its old habits, putting the new constitution on ice almost as if no referendum had taken place.

Here the story will be recounted in three parts. First, for the reader to understand Iceland's precarious political situation, it is necessary to provide historical background to the post-crash constitutional revision process. Second, drawing on earlier writing, I will offer a brief account of some aspects of the constitution-making process during 2010-2013, including the work of the Constituent Assembly of which I was a member. Third, I will describe the Parliament's ongoing attempt to undermine the substance of the constitutional bill accepted in the 2012 referendum.

\section{Background}

After the collapse of Iceland's entire banking system in 2008, resulting in the destruction of assets equivalent at the time to seven times the country's annual GDP, ordinary people from all

\footnotetext{
${ }^{1}$ Stanford Dictionary of Philosophy, see http://plato.stanford.edu/entries/legitimacy/. See also Beetham (2013).

${ }^{2}$ See https://www.youtube.com/watch?v=IthLUGAjsdI. The quoted words begin at 3:59.
} 
walks of life took to the streets to confront their visibly shaken politicians who, to their credit, threw in the towel when the Pots and Pans Revolution culminated with the protesters singing patriotic songs on the front steps of the Parliament building, knowing that if the Red Army did not dare try to suffocate the Singing Revolution in the Baltic countries 1987-1991 the Icelandic police would show similar restraint; the Vice Chief of Police, in full gear, a good singer, joined the National Choir outside Parliament. The game was up.

The government resigned, paving the way for a new parliamentary election two months later, in April 2009, an election that produced a majority government including neither the Independence Party nor the Progressive Party which had, one or the other if not both at once, governed Iceland virtually without interruption throughout the history of the Republic, founded in 1944 when Iceland unilaterally declared full independence from Nazi-occupied Denmark. Over the years, those two parties had seen their combined vote in parliamentary elections decrease from $70 \%$ to less than $50 \% .{ }^{3}$ Simply put, their legacy is (a) economic advances that enabled Iceland within two generations to close the gap in living standards as measured by per capita incomes that had separated Iceland from Denmark in 1904 when Iceland was granted home rule by Denmark and (b) a country whose politics is considered corrupt by $67 \%$ of Gallup's Icelandic respondents compared with $14 \%$ in Sweden and 15\% in Denmark (Gallup 2013). ${ }^{4}$ Around 1900, Denmark was roughly twice as affluent as Iceland in terms of per capita GDP. In 2007, Iceland shared with Norway first place in the UN's Human Development Index (HDI), sliding to $16^{\text {th }}$ place in 2014 six years after the crash.

As O’Toole (2010) has written of Ireland, Iceland is, in economic terms, a first-world country marred with a third-world political culture. This was duly acknowledged by Parliament itself in its unanimous 2010 resolution, adopted with 63 votes to zero, no abstentions, that "criticism of its political culture must be taken seriously" (my translation). In fact, Iceland's political class leaves behind a long record of corrupt, criminogenic behavior, including bank scandals that were swept under the carpet in the 1930s, illegal profiteering around the U.S. military base in the

\footnotetext{
${ }^{3}$ From 1944 to 2015, the Independence Party was in government for 54 years, the Progressives for 46 years, the Social Democrats for 36 years, and the Left-Greens and their predecessors for 19 years. During 2007-2009, the Social Democrats were in government with the Independence Party with the Progressives and Left-Greens in opposition.

${ }^{4}$ Gallup asked about political corruption whereas Transparency International, which also ranks Iceland behind other Nordic countries, asks about business corruption. The World Values Survey (2014) ranked interpersonal trust in Iceland far behind that in other Nordic countries even long before the crash of 2008 (Gylfason, 2015b). These surveys were taken before Iceland surfaced at the center of the Panama Papers scandal in early 2016.
} 
1940s and 1950s, and Russian-style treatment of natural resources since the 1980s, declared unconstitutional by the Supreme Court in 1998 (Kristjánsson, 2011). Under political pressure, the Supreme Court reversed its verdict eighteen months later only to have it reconfirmed in 2007 by the United Nations Human Rights Committee (2007) which, in a binding opinion, instructed Iceland to remove the discriminatory element from its fisheries management system and pay damages to those who had been discriminated against. In 2012, the UNHRC let Iceland off the hook against the government's promise of a new constitution guaranteeing a nondiscriminatory allocation of fishing rights. All this was accompanied by a strong dose of asset stripping à la russe, including a corrupt privatization of the banks that paved their road to the cliff in 2008 and that Parliament has proved unwilling to investigate. It was not until after the crash of 2008 that the IMF openly expressed support for a fee-based and nondiscriminatory - i.e., constitutional system of fisheries management in Iceland.

To begin with, the new post-crash government listened to the people and their demands. The ex-Prime Minister turned Governor in Chief of the failed Central Bank, mired in controversy, ${ }^{5}$ was removed from office only to be installed by the oligarchs as editor of what used to be Iceland 's largest newspaper. The oligarchs are mostly vessel owners enriched by Parliament's granting them hugely valuable fishing quotas since 1984. The IMF was called to the rescue following a botched attempt by the Central Bank to procure a big loan from Russia to avoid IMF assistance or the "Kiss of Death" as one key Independence Party operative described it (Gunnarsson, 2009, 51). No political party distanced itself from the Central Bank's overture to Russia which came to nothing (Iceland is a founding member of NATO). A Special Prosecutor"s Office was set up, and managed to secure a number of convictions of senior bankers and others, but some of those convictions remain on appeal to the Supreme Court. In mid-2016, the Supreme Court had sentenced bankers and others to a total of 70 man-years in prison for crash-related offences, including breach of trust, market manipulation, false reporting, and fraud. Several

\footnotetext{
${ }^{5}$ Wade (2009) and the Special Investigation Committee (SIC, 2010) describe the ill-fated pegging of the króna to the euro when there were hardly any foreign exchange reserves left, a decision made by the Central Bank governors without consultation even with the bank's chief economist, triggering a still unaccounted-for hemorrhage of remaining reserves. The Central Bank has refused to share with Parliament, let alone make public, a recording or transcript of a telephone conversation just before the crash between the governor and the Prime Minister who was later along with two other ministers, the three Central Bank governors, and the director of the Financial Supervisory Authority declared guilty of negligence in the sense of the law by the SIC (2010). The former Prime Minister, Geir Haarde, was likewise found guilty of negligence by a special Court of Impeachment convened by Parliament in 2012 and headed by the Chief Justice of the Supreme Court, and was appointed ambassador to the U.S. in 2014.
} 
further indictments and verdicts are expected to result from the roughly 80 cases referred to the Special Prosecutor by the Financial Supervisory Authority (FME) which, designed as it had been to fail, had slept through the crash alongside the international rating agencies but was now alert under a new post-crash director who, three years and 77 referrals to the Special Prosecutor later, was hounded from office. In 2010, a 2,400-page report by a Special Investigation Committee (SIC) appointed by Parliament described legal violations on top of recklessness, regulatory capture, political capture, media capture, academic capture, and so on, even if the report failed to connect its analysis to the relevant law-and-economics literature on white-collar crime (Akerlof and Romer, 1993; Black, 2005). ${ }^{6}$ The academic capture part of the story is recounted to chilling effect in Ferguson (2012, Ch. 8). Parliament discussed the report only cursorily.

A key promise given by the post-crash government in early 2009 concerned the constitution which, drawn up in haste at the time of Iceland's full separation from Denmark in 1944, Parliament had promised to revise ever since without keeping its promise, partly perhaps because it was not impelled by crisis to do so (Elster, 1995). In his New Year's address to the nation in 1949, Iceland's first president, Sveinn Björnsson, reminded the political parties of their failure to fix the constitution, saying that "... we still have a mended garment, originally made for another country, with other concerns, a hundred years ago“ (my translation). The post-crash government concluded that since the politicians had failed to revise the constitution for almost 70 years it was time to bestow the task on a special Constituent Assembly - that is, to have a new constitution drafted by representatives elected directly by the people rather than by Parliament. This promise constituted a welcome admission of failure as well as an undeclared acknowledgement that a constituent assembly elected in accordance with the principle of 'one person, one vote' was better suited to the task than MPs elected on the basis of current electoral laws granting rural voters on average twice as much influence in parliamentary elections as voters in the Reykjavík area, one of the most controversial issues in Icelandic politics since 1849 when the first written proposal of equal voting rights - equal apportionment of seats in Parliament if you prefer - was put forth, but in vain.

\footnotetext{
${ }^{6}$ Johnsen (2014) reviews the main findings of the SIC report. For a short version of some of the highlights of the story, see Gylfason (2010). For more on the crash in a historical and political context and its aftermath, see Gylfason et al. (2010, Ch. 7), and Gylfason (2015a, 2016).
} 
So, it is important for the reader to understand that the trouble with Iceland started long ago. We could begin the story in the 1870s, but let us wind fast forward to the 1940s and World War II that saw a unilateral decision by Parliament and the electorate to leave the royal union with Nazi-occupied Denmark, unable to fend for itself. The political parties stood united behind this decision and made an all-out effort to muster the support of $98 \%$ of the voters for the decision plus a new constitution, essentially a copy of the Danish one from 1849 with a hereditary king replaced by a president. The parties could enlist broad popular support by promising a new constitution. Meanwhile, the main political parties got along miserably with one another due, among other things, to a deep disagreement about unequal voting rights that culminated in a 1942 constitutional amendment designed to reduce the rural bias of the electoral laws. The Progressive Party, the main beneficiary of unequal voting rights because of its strength in rural areas, fought the amendment tooth and nail, and lost. The political parties were unable to form a coalition government, inducing the governor, Sveinn Björnsson, elected president in 1944 when the Republic of Iceland was established, to appoint an extra-parliamentary government 19421944, albeit one firmly anchored in the dominant political parties, the Independence Party and the Progressives, virtually not on speaking terms with one another.

The 1950s saw an uneasy truce among the dominant parties, a truce that was broken in a new battle in 1959, as in 1942, about a constitutional amendment to secure more equal voting rights. Once more, the Progressives, still heavily overrepresented in Parliament, fought fiercely against the amendment, and lost again. As a result, the two main parties were unable to work together again until the mid-1970s. All along, the economy remained heavily regulated with prices, interest rates, and the exchange rate of the króna determined by politicians and their apparatchiks in the banks. An important respite was provided by a major economic liberalization effort in the 1960s when huge fiscal subsidies to the fishing industry were converted to indirect support through devaluation of the króna and privileged access to subsidized bank credits, an arrangement meaning essentially that the króna would be devalued at the whim of the vessel owners to shore up the profitability of fish exports when needed, undermining financial conscientiousness in Iceland's main export industry. In the 1980s and 1990s an attempt to stabilize the króna meant that government support for the fishing industry thereafter took the form of gratis allocations of hugely valuable fishing rights in Icelandic waters, even if the marine resources were shortly thereafter declared a common property resource by law. The system of 
gratis quota allocations, ruled discriminatory and unconstitutional by the Supreme Court in 1998 and by the UNHRC (2007), turned a dispersed resource (fish) into a concentrated one (like oil), with all the potential for political cartelization that implies (Wenar, 2016). From then on, the vessel owners were basically able to call the shots in Icelandic politics with a brief interlude during the 2000s when exuberant bankers briefly ran the show until the crash of $2008 .{ }^{7}$ The editor of one of Iceland's two main newspapers at the time described as 'suicidal' attempts by politicians to rise against the quota kings. ${ }^{8}$ The SIC (2010) reports huge payments by the failed banks, before their demise, to political parties and individual politicians, information that would not have come to light without the crash.

President Björnsson, as governor in 1944, emboldened by the first scientific public opinion poll conducted in Iceland, managed to have two key novelties inserted into the provisional constitution that was otherwise kept essentially unchanged from 1874, or 1849. ${ }^{9}$ The novelties were that the President of the Republic (a) would be elected by the people, not by Parliament as the political parties wanted (this gave Iceland one of the first popularly elected presidents in Europe $)^{10}$ and (b) could veto legislation from Parliament and refer it to a national referendum, a provision that lay dormant for 60 years until it was activated in 2004 to block the government's plan to regulate media ownership in a way that would have forced Iceland's largest daily newspaper and the sole television station competing with state television to close down.

Constitutions are by their very nature political declarations outlining the rights and obligations of citizens, including the powers of the organized few versus the unorganized masses and, as such, are naturally conducive to deep disagreements about individual provisions. Rights protected in constitutions entail obligations that may understandably meet resistance. Those who claim that constitutional amendments must be approved by consensus are fundamentally at odds with the historical evidence as well as basic logic, but their position serves the special interests of those opposed to constitutional reform, a point I shall return to in Section 3 dealing with the

\footnotetext{
${ }^{7}$ For an account of events in Iceland before and after the crash, see Gylfason et al. (2010), Benediktsdóttir, Daníelsson and Zoega (2011), Johnsen (2014), and Gylfason (2015a).

${ }^{8}$ See Gunnarsson $(2009,206)$. "Quota kings" and "quota queens" are commonly used terms in public debate in Iceland, like "oligarchs" in Russia. By contrast, oil kings and oil queens are unheard of in Norway because the Norwegian government made sure from the outset that Norway's oil discoveries would not result in the creation of a class of oligarchs.

${ }^{9}$ On the 1,000th anniversary of the settlement of Iceland in 1874 Christian IX, King of Denmark, brought the Icelanders their first constitution, essentially identical to the Danish constitution of 1849.

${ }^{10}$ Precedents include France in 1848 and Germany in 1919.
} 
parliamentary constitutional committee's efforts to water down three provisions of the bill approved by the voters in the 2012 referendum. But first let me offer some remarks on the work of the Constituent Assembly in Section 2.

\section{Constitution making in action 2010-2013 ${ }^{11}$}

With the political class up against the wall after the crash of 2008, a new Icelandic constitution was promised once again. As the coalition government of the Social Democratic Alliance and the Independence Party stepped down in early 2009 under public pressure, the Social Democrats went on to form a minority government with the Left-Green Party, with the support of the Progressives who made their support conditional on having a new constitution put in place, to be drafted by the people rather than by politicians. After the 2009 election, the two parties of the minority coalition were able to form a majority government. An attempt at constitutional overhaul seemed inevitable at this stage, with the Independence Party, a conservative force in Icelandic politics, reluctantly agreeing to a bill regulating the constitutional revision process (Meuwese, 2013). To its credit, the Independence Party proposed the convention of a National Assembly. During 2009-2013, the Independence Party and the Progressives found themselves together in opposition in Parliament for the first time in history.

In June 2010 Parliament passed the Act on a Constitutional Assembly, laying out a process that included preparations for the drafting by a seven-member extra-parliamentary Constitutional Committee, appointed by Parliament. A National Assembly comprising 950 individuals drawn at random from the National Register convened for a day in November 2010, declaring at the end of its deliberations that a new constitution was needed and should include certain key provisions on equal voting rights and national ownership of natural resources, among other things. A national Single Transferable Vote election of 25 Constitutional Assembly representatives from a roster of 522 candidates was held 27 November 2010; the STV method is designed to minimize the number of dead votes (Helgason, 2011). The Constitutional Committee produced a 700-page dossier analysing the 1944 constitution and including suggestions of new constitutional text for the Constitutional Assembly to consider.

\footnotetext{
${ }^{11}$ This section draws on Gylfason and Meuwese (2016).
} 
Former Prime Minister Geir Haarde from the Independence Party was indicted by Parliament in September 2010. He was subsequently cleared of all but one offence, failing to keep his ministers sufficiently informed during the 2008 financial crisis in violation of the constitution. An ad hoc parliamentary committee had decided that four former ministers should be indicted, but Parliament, including current and former ministers who did not recuse themselves from the proceedings, decided to spare all except the former Prime Minister. This triggered an unforgiving reaction from the Independence Party, now in opposition, thus extinguishing the hope that government and opposition could unite in honoring their promise to the people of a new constitution.

Undeterred by events in Parliament, and with a strong mandate from of the public, the Constitutional Council commenced its work on 6 April 2011. The Council convened for a bit less than four months, until 28 July 2011, unanimously - i.e., with 25 votes against zero - approving the constitutional bill on 27 July, using 28 July to polish and approve the Preamble in time for the complete text to be delivered to the Speaker of Parliament 29 July 2011. No other MPs attended the ceremony.

Several factors contributed to the production and unanimous passage of a constitutional bill combining continuity with fairly radical reform in several areas, including equal voting rights, national ownership of natural resources, freedom of information, environmental protection, and more. First, the bill was consistent with the conclusions of the National Assembly (Gylfason, 2016). Second, public opinion polls reflected a broad consensus on key constitutional issues. Third, the method used to elect the Council members - one person, one vote combined with STV - produced a group of uniformly competent people from different walks of life with a wide range of professional experience, including five professors and three other academics used to soliciting outside expertise. In the first few days of the Council's deliberations, it was decided to draft a new bill from scratch, as was done in Philadelphia in 1787, rather than amend the 1944 constitution. This was done with due respect for constitutional continuity as Elkins et al. (2012) emphasize in their review of the bill. Also, it was decided to invite outsiders to participate through a specially designed interactive website as well as through social media. The Council website was designed around this process to underscore the popular nature of the constitutionmaking exercise as opposed to constitution-making by politicians and their lawyers.

The open invitation to the public had an important additional benefit in that it made it 
unnecessary if not inappropriate to invite representatives of interest groups to meet with the Council the way that, for example, the South African constitution was put together during 19941996. This invitation was in the spirit of the opening sentence of the Preamble: "We, the people of Iceland, wish to create a just society with equal opportunities for everyone.” After some exchanges between the Parliament and the Council, Parliament called for an extra four-day Council meeting in March 2012 for the Council to answer some questions about its text. At this meeting the 21 Council members present (four of the 25 could not attend) gave unanimous answers to the Parliament's queries, in some cases suggesting alternative formulations without changing the substance of the provisions in question. Not long thereafter, Parliament decided to put the bill to a referendum. The opposition in Parliament - the Independence Party and also the Progressives who had reversed course - now fought against the reform process tooth and nail, managing to delay the referendum beyond the presidential election 30 June 2012, a date preferred by the government on the grounds that voter turnout is always high in presidential elections. Instead, the referendum was held 20 October 2012. The bill as a whole as well as its key provisions put on the ballot by Parliament won overwhelming support across the board with only two exceptions: the provision on equal voting rights was not accepted in two of the three rural constituencies and the provision on church and state was not approved. The overall support for the bill was $67 \%$, the support for equal voting rights was also $67 \%$, and for national ownership of natural resources, $83 \%$. Turnout was $49 \%$, a remarkably high figure in view of the fact that the referendum was an orphan. Even the government coalition parties that called the referendum did almost nothing to promote the bill or to encourage their supporters to vote. It fell on the smallest party in Parliament, an opposition party with three seats out of 63, and on ordinary citizens, including former Constitutional Council members whose mandate had expired long ago, to travel around the country at their own expense to present the bill to the voters.

After the referendum, the haggling in Parliament intensified. The majority in Parliament that had shown little interest in its own referendum proved an easy prey for the fierce opponents in the minority which, with the economy gradually recovering under the IMF-supported rescue program, sensed that the shadow of the financial crash grew shorter and shorter. Even if 32 MPs out of 63 had declared in writing their support for the parliament's ratification of the bill in accordance with the outcome of the referendum, Parliament adjourned in March 2013 without having put the bill to a vote. 
According to the 1944 constitution, it can be amended by a simple majority in two successive parliaments with a general election in between. The strategy of the supporters of the bill was to pass the bill unanimously in the Constitutional Council and go on to win the referendum by a solid majority of the voters thus making it inevitable for Parliament to ratify the bill before the 2013 election and thus, ultimately, making it difficult for a new Parliament after the 2013 election to refuse to provide the second ratification without provoking riots. This strategy failed because Ásta Ragnheiður Jóhannesdóttir, Speaker of Parliament, violating parliamentary procedure, failed to bring the bill to a vote before Parliament adjourned 27 March 2013.

\section{Parliament's constitutional committee 2013-2016 ${ }^{12}$}

Six months into his new government's term, the Prime Minister appointed a constitutional committee in November 2013, the latest in a long line of such committees since the 1940s. The new committee comprised two members representing each of the two governing parties, the Independence Party and the Progressives, and one each from the four smaller opposition parties plus a chairman appointed by the Prime Minister. The committee's official mandate was to present to Parliament constitutional text for Parliament's approval based on the bill approved in the 2012 referendum. The committee's unofficial mandate was to reach consensus by preparing a document that all nine committee members could sign - that is, find the lowest common denominator. The setup was deeply flawed. It amounted to an undertaking to negotiate after the fact with those who had lost the 2012 referendum. The thinking behind this setup recalls President John F. Kennedy's famous dictum: "What's mine is mine, what's yours is negotiable." Everyone knew that the committee was destined if not designed to fail as had all earlier constitutional committees appointed by Parliament for 70 years.

The committee can be said to have been appointed deliberately to look for ways to water down or disregard the results of the 2012 referendum. A clear first sign of things to come was the Prime Minister's choice of chairman of the committee, a retired law professor in his eighties who had repeatedly declared himself opposed to constitutional change both before and after the 2012 referendum. When he retired in 2014 "due to age and other work" the committee chair was

\footnotetext{
12 This section draws on my comments to the Parliament's constitutional committee, published in Fréttablaðið, Iceland's largest newspaper, as well as on the Parliament's website. The committee received comments, most of them devastatingly critical, from 63 individuals.
} 
transferred to a lawyer in the Prime Minister's Office, an individual who previously as head of a small group of local lawyers had been seen to violate the clear instructions of the Constitutional and Supervisory Committee (CSC) of Parliament during 2012-2013 by proposing material changes in the Constitutional Council bill against the express instructions of the CSC that the lawyers' team was authorized solely to propose changes in wording but not in substance. The CSC understood then that Parliament could not permit itself to disregard the will of the voters as expressed in the referendum of 2012 in much the same way as the U.S. Congress did not permit itself to change as much as a word in the bill proposed by the Constitutional Convention in Philadelphia in 1787, neither before nor after the bill was brought to a vote in the states.

It behooves to recall how the chairman of the constitutional committee disobeyed the instructions of the CSC during 2012-2013. Along with a few other lawyers chosen by the CSC the chairman delivered to the CSC a radically revised statement concerning the Constitutional Council's natural resource provision. The revised statement repeatedly maintains with different wording that "The provision does not affect such property rights to resources that may already exist and the entitlements implied by such rights." (My translation, here and below.) Also: "The provision does not affect utilization permits or indirect property rights already in existence." And this: "in accordance with the intentions of the Constitutional Council [my italics, TG], that those property rights already in existence, protected by the constitution, will not be affected." None of this is consistent with the original statement of the Constitutional Council. The lawyers, moreover, seemed to suggest that vessel owners had acquired property rights to catch quotas even if both the current law on fisheries management and the Constitutional Council's bill clearly state that this is not the case. Did the lawyers think that the Constitutional Council's natural resource provision had been passed unanimously by 22 votes (two abstained, one representative was absent), followed by spontaneous applause, to celebrate unchanged fisheries management? Did they think that $83 \%$ of the voters had approved the Constitutional Council's natural resource provision to nail down an unchanged fisheries policy regime? Former Constitutional Council representatives pointed this out to the CSC at the time as did many others.

This account is needed to shed light on the background of the work of the Parliament's constitutional committee at its 48 or more meetings since 2013, all held behind closed doors, with only minimal information given sporadically to the public. The committee selected just four of the 114 provisions in the Constitutional Council bill for revision and ultimately gave up on 
reaching agreement on one of the four, the one dealing with transfer of state powers considered by many crucial to avoid constitutional challenges to, e.g., Iceland's pending application for EU membership, filed by Parliament in 2009 and laid on ice in 2013 by the current government, not by Parliament. What happened here is that opponents of EU membership - that is, the majority of the four government representatives on the committee plus the chairman - do not want the constitution to permit membership. This outcome, if allowed to stand, would make Iceland unique in Europe. ${ }^{13}$ Thus, by refusing to accept the Constitutional Council bill's provision on transfer of state powers, the opponents of reform thereby declare that they do not accept the right of the people to decide by popular referendum whether Iceland should join the EU or stay out even if this is an inalienable right conferred on the people in the bill.

This omission left the committee with three provisions all of which it has sought to weaken compared with corresponding provisions in the Constitutional Council bill. The committee seems to have sought the lowest common denominator to cater to those who lost the referendum in 2012 as if election results can subject to negotiation after the fact. The result is three draft bills that are essentially inconsistent with the results of the referendum, leading the representatives of two of the parliamentary parties on the Committee, the Social Democrats and the Pirate Party, to publicly express dissatisfaction with the draft bill and thus to break ranks with the rest of the committee. The Pirate Party which in opinion polls since 2014 has consistently received support from well over a third of the voters has resolved to respect the results of the 2012 referendum. The Social Democratic member of the Parliament's constitutional committee, Ms. Valgerður Bjarnadóttir who chaired the Parliament's CSC during 2012-2013, has written: "The outcome [i.e., the constitutional committee's proposal] is what the reactionaries [i.e., opponents of constitutional reform] can accept." ${ }^{14}$ Hence, the Parliament's plan to produce unanimity has already failed.

It can be said that the three bills submitted by the committee constitute an improvement on the 1944 constitution, but they constitute a much smaller improvement than that approved by the voters in the 2012 referendum. Others think that acceptance of anything from the Parliament's constitutional committee is tantamount to acquiescence to a coup against democracy.

\footnotetext{
${ }^{13}$ Denmark introduced a clause on the transfer of state powers into its constitution in 1953 to remove a potential obstacle to foreign relations, including EU membership, and Norway did so in 1962.

${ }^{14}$ See http://herdubreid.is/um-stjornarskrartillogurnar/
} 
[Type here]

Let me now discuss the specific ways in which the constitutional committee bills subtract from the Constitutional Council bill.

\section{A. Natural resources}

The constitutional committee's draft bill on natural resources is characterized by retreat. The tone is set right from the start: "Iceland's natural resources belong to the Icelandic people." The Falkland Islands belong to Britain, true, but the British do not own them. The statement accompanying the bill admits the retreat (p. 17): "This wording does not refer to traditional property rights." The implication is that national ownership is inferior to other forms of ownership. (The first chairman of the constitutional committee is known for having stuck to the view that there can be no such thing as national ownership.) The committee reaffirms its retreat by replacing the words "common and perpetual property of the nation" at the very beginning of the provision by a simple reference to "property of the nation" in the middle of the text - i.e., neither common nor perpetual. Further, the stipulation that "government authorities may grant permits for the use or utilization of resources or other limited public goods against full consideration and for a reasonable period of time" is replaced by a formulation where the word "full" is replaced by "normally fair", a double discount to the vessel owners. In addition, the time limit "for a reasonable period of time" has been removed.

The statement with the draft bill does not mention whether it is "normal" for vessel owners to expropriate $90 \%$ of the fisheries rent as has been the case thus far (Thorláksson, 2015). A representative in the constitutional committee has said publicly that he prefers "normally fair" consideration to "full" consideration on the grounds that this would facilitate support for socially important projects, etc., through a constitutionally protected discount from full charge. This idea entails that a harmful and outdated method of economic management - hidden indirect subsidies in lieu of transparent direct subsidies through the government budget - be enshrined in the constitution. The words "which are not in private ownership" have been replaced by "which are not subject to private property rights." Here an unambiguous choice of words by the Constitutional Council - everyone knows what "private ownership" means - is let give way to unclear and ambiguous wording that invites legal dispute. Everyone knows that vessel owners eventually do not own the fish in the sea for that is the law, but they could try to claim to have earned property rights to the resource. 
The statement with the constitutional committee's bill has indeed no legal force, but, if allowed to stand, it is likely to undermine the advancement of their rights that the voters granted themselves when $83 \%$ of them expressed their support in 2012 for the national ownership provision proposed in the Constitutional Council bill. The constitutional committee statement declares that its bill "does not, however, automatically lead to change in current utilization permits" and "the provision will not automatically disturb the indirect ownership rights that may be implicit in the utilization or exploitation rights that may already have been established vis-àvis state rights and resources that according to the bill will be considered in public ownership." The report thus conveys the impression that vessel owners have, in effect, acquired some form of ownership rights to the fisheries. The report also says: "If the fee is not determined in the market it can be expected that the fee be based on the profitability of exploitation ..." The message of the constitutional committee to the vessel owners is clear: Just keep piling up debts and you will be granted a constitutionally guaranteed discount as a matter of course.

The constitutional committee includes a single academic reference in its statement (Willmann and Kelleher, 2009), ${ }^{15}$ a World Bank study known for its advocacy of privatization of commonproperty fisheries, without referring at all to the literature explaining the efficiency gains from regulating access to common property resources in a non-discriminatory fashion by fee.

Just as the constitutional committee tries to demote the concept of national ownership, it downplays the concept of sustainable development by removing the sentence "The utilization of the resources shall be guided by sustainable development ...," replacing it by a weaker formulation as follows: "They [Iceland's natural resources] ought to be utilized in a sustainable way ..." The phrase "sustainable development" is by now deeply anchored in international discourse on environmental protection whereas "utilized in a sustainable way" has no such direct connotation and is, therefore, legally ambiguous. ${ }^{16}$

The statement with the draft bill of the constitutional committee discusses at length various legal texts of limited relevance but fails to mention the seminal 1998 Supreme Court verdict that declared the fisheries management system to be discriminatory and thus in breach of the current

\footnotetext{
${ }^{15}$ I owe this observation to the comments submitted to the constitutional committee by dr. Níels Einarsson, Director of the Vilhjálmur Stefánsson Institute at the University of Akureyri.

${ }^{16}$ I owe this observation to the comments submitted to the constitutional committee by my fellow Constitutional Council member Mr. Ómar Ragnarsson, Iceland's most prominent environmentalist together with Björk.
} 
constitution. Nor does the statement mention the binding opinion of the UNHRC of 2007 which confirmed the 1998 verdict of the Supreme Court.

The statement also offers a revealing paragraph: "There can hardly be found any examples of economies that are as dependent on natural resource utilization as the Icelandic one." This statement is not only false (the fishing industry accounts at present for $10 \%$ of Iceland's GDP and $25 \%$ of export earnings) but this is a worn piece of propaganda from the National Federation of Icelandic Fishing Vessel Owners (LÍÚ, now SFS). That this rehash of an old untruth should find its way into the constitutional committee statement is worthy of note in view of the welldocumented fact that the first quota law was drawn up in the offices of LÍÚ (Jónsson, 1990). Nearly half of all countries of the world are more dependent on natural resources than Iceland based on World Bank figures on natural resource rents in proportion to GDP and comparable data for Iceland compiled by Mr. Indriði H. Thorláksson (2015), former director of Revenue Iceland.

The constitutional committee's statement with its draft bill on natural resources needs to be rewritten and rectified so as to reflect fully the statement of the Constitutional Council with its resource provision which, among other things, offers a precise definition of the concept of national ownership as distinct from state ownership and private ownership, a concept that the constitutional committee has tried to disparage in accordance with its original chairman's view that there is no such thing as national ownership even if practically every Icelander knows exactly what that means. For example, the law from 1928 about the national park at Thingvellir, the venue of Iceland's ancient parliament, declares the park to be the property of the nation.

\section{B. Environment and conservation}

The constitutional committee bill on the environment also misses the mark. Telling is the committee's removal of the Constitutional Council's sentence "Previous damage shall be repaired to the extent possible" from the text. This sentence was included in the Constitutional Council bill to acknowledge Iceland's perhaps most serious environmental problem, soil erosion largely due to private grazing on public lands. The constitutional committee seems to have omitted the sentence to defer to those bent on continued degradation of the environment. The sentence "Everyone is under obligation to respect it and protect it [Iceland's nature]" has been

omitted apparently for the same purpose. Further, the reference to "protection of sites of natural 
interest, unpopulated wilderness, vegetation and soil" has been omitted without explanation even if the wording of the omitted text was carefully argued in the statement of the Constitutional Council with its bill with reference to the experience of other countries. Finally, the constitutional committee has deleted without explanation the Constitutional Council's text elaborating the meaning of sustainable development, including the reference to the rights of nature and future generations: "The use of natural resources shall be managed so as to minimize their depletion in the long term with respect for the rights of nature and future generations."

\section{Direct democracy}

Like its other two draft bills, the constitutional committee's bill on direct democracy subtracts a great deal from the corresponding provisions in the Constitutional Council bill. This is remarkable in view of the fact that in the 2012 referendum $73 \%$ of the voters declared themselves in favor of direct democracy with increased reliance on national referenda. The constitutional committee narrows considerably the provision of the bill approved by the voters by (a) increasing the minimum number of signatures by half, from $10 \%$ to $15 \%$ of the electorate, without comment on the Constitutional Council's careful justification for the $10 \%$ mark; (b) reducing the time available for collecting signatures demanding a referendum from three months to four weeks (a bungle, according to a public statement by a member of the committee); (c) introducing a de facto threshold for minimum participation in national referenda that is so high as to make the provision likely to be a dead letter; ${ }^{17}$ and (d) by removing altogether the provision on parliamentary business on the initiative of voters, stipulating, in the words of the Constitutional Council, that "two per cent of the electorate may submit an item of business in the Althing [Parliament]." Put bluntly, the revised provision on direct democracy offered by the constitutional committee constitutes a frontal assault on the people of Iceland and their democracy.

\footnotetext{
${ }^{17}$ Specifically, the provision stipulates that to overturn bills approved by Parliament in a referendum requires not only a majority of the votes but also at least $25 \%$ of the electorate. Average participation in national referenda in Iceland since 1908 (except 1944, a special case) is 57\%. If a government supported by 33\% of the voters (as at present) instructs its supporters to stay at home, bringing voter participation down to $38 \%$, it would take a $66 \%$ majority of the voters (i.e., 25/38) to overturn the legislation.
} 


\section{Conclusion}

The bills proposed by the constitutional committee reveal a clear determination by the current majority in Parliament to disrespect the will of the people as expressed in the 2012 constitutional referendum. The bills are clearly intended to accommodate special interests, those forces that were mostly responsible for putting Iceland on the rocks in 2008 and again in 2016, inflicting serious damage on the country and its reputation in the eyes of the rest of the world. Every single departure from the Constitutional Council bill seems designed to subtract from the bill and to serve the interests of the political class and connected special interests at the expense of the people. Parliament enjoys limited trust among voters, scraping the bottom along with the banking sector and the Financial Supervisory Authority in the public opinion surveys by Capacent (18\% trust the parliament) and MMR (14\% trust the parliament). ${ }^{18}$

Following the National Assembly of 2010 and in keeping with a legal process laid out by Parliament, the Constitutional Council bill answered the call of the people for a new constitution, new mores, a new political culture, a new beginning. The bills proposed by the Parliament's constitutional committee aim to undermine this appeal, not only by watering down three provisions in the Constitutional Council bill but also by ignoring everything else, including the provision on equal voting rights (equal apportionment), a key provision of the bill, and also the provision on the transfer of state powers. Without a new electoral provision the next parliamentary election will be held under election laws that $67 \%$ of voters rejected the 2012 referendum. Without a new provision on the transfer of state powers MPs will continue to face accusations that they deliberately violate the current constitution which does not contain a clear transfer provision.

The seriousness of the Parliament's failure to abide by the results of the 2012 national referendum manifests itself in many ways. Here two examples will do.

First, an absurd provision of the 1944 constitution remains in force, an obvious remnant from the mid- $19^{\text {th }}$ century where kings reigned supreme: "The President grants, either himself or through other government authorities, exemptions from laws in accordance with rules that have

\footnotetext{
${ }^{18}$ These surveys were taken before the Prime Minister, Finance Minister, and Minister of the Interior along with several other politicians were exposed as holders of significant amounts of money in international tax havens, including the one that has become virtually synonymous with the goings on before Iceland's financial crash of 2008, Tortola in the British Virgin Islands. In early April 2016, the Panama Papers threw Iceland into political turmoil resulting in the sudden resignation of the Prime Minister and the formation of a new government, though in name only.
} 
been followed thus far." Yes, you might add, and in accordance with President Richard Nixon's final dictum in this 1977 television interview with David Frost: "If the President does it, that means it's not illegal." While this provision has not been invoked to date, it is out of place and perilous in a modern democracy where business, finance, and politics intermingle to an unprecedented degree and where 28 individuals have been awarded prison sentences for crashrelated violations of the law and where further guilty verdicts appear likely.

Second, the outmoded 1944 provision on the election of the President remains in force. This provision awards the presidency to the candidate with the largest number of votes without requiring that the victor enjoys the support of the majority of voters. The Constitutional Council anticipated the danger that a large number of candidates might result in the election of a President with a small plurality, perhaps $20 \%$ of the vote or less. This is why the bill stipulates that "Voters shall rank candidates, one or more, at their own choice in order of preference. The person who best meets the order of preference of voters, as further provided by law, is the rightfully elected President." This insures that the candidate elected has the majority of votes even without a second round of voting. Further, the bill stipulates that "Presidential candidates shall have the endorsement of a minimum of one per cent and a maximum of two per cent of the electorate." This means that a candidate would need to secure a minimum of 2,400 signature compared with the current requirement of 1,500 signatures, a much lower threshold. Nine candidates ran for president in June 2016. Had eight of them received $11 \%$ of the vote each, the ninth would have won with $12 \%$ support. This did not happen, however. As it turned out, the winner received $39 \%$ of the vote, followed by three other candidates with $28 \%, 14 \%$, and $14 \%$. By sheer luck, the danger of a new President with miniscule public backing was thus averted. Even so, like the parliamentary election promised in the wake of the Panama papers scandal to be held ahead of schedule in the fall of 2016 rather than the spring of 2017, the presidential election in June 2016 was held according to laws that the voters have rejected, bearing still further testimony to the Parliament's deplorable handling of the constitutional reform process in Iceland.

The chain of political legitimacy in Iceland is on the verge of being broken unless swift corrective action is taken. The argument rests on four main pillars.

First, a politically motivated, substantively wrong, and even illegal Supreme Court decision invalidating the Constituent Assembly election of 2010 was intended to kill in its infancy, or at 
least to undermine, what is probably the most democratic constitutional reform process the world has ever seen.

Second, while the National and Constituent Assemblies delivered on schedule everything expected of them by law, the Parliament failed to do its part by refusing to bow to the will of the people by ratifying the constitution bill approved by two thirds of the voters in 2012 .

Third, Parliament added insult to injury by reversing its original determination to outsource the drafting process to the Constituent Assembly and by effectively reclaiming the right to meddle with the substance of the Constituent Assembly bill even after the bill had been overwhelmingly approved by the voters, ultimately producing nothing of value while the government plunged the country into political crisis in the wake of the Panama papers scandal.

Fourth, the Parliament's constitutional committee has presented proposals that constitute a gross diminution of the bill that was accepted in the 2012 referendum, proposals that were poorly received by the public and seem almost certain to stall in Parliament.

A democratic nation cannot under any circumstances permit the outcome of national elections, let alone a constitutional referendum, to be changed after the fact even if the referendum was advisory. Yet, this is what the Icelandic Parliament is at present trying to do, flirting with a farewell to its political and moral legitimacy as well as to democracy. 
[Type here]

\section{References}

Akerlof, George A., and Paul M. Romer (1993), "Looting: The Economic Underworld of Bankruptcy for Profit," Brookings Papers on Economic Activity 2, 1-73.

Beetham, David (2013), The Legitimation of Power (2 ${ }^{\text {nd }}$ ed.), Palgrave MacMillan, London.

Benediktsdóttir, Sigríður, Jón Daníelsson, and Gylfi Zoega (2011), “Lessons from a Collapse of a Financial System," Economic Policy 26, 183-235.

Björnsson, Sveinn (1949), “Nýársávarp til pjóðarinnar” (New Year’s Address to the Nation). Accessed November 17, 2014, www.forseti.is/media/files/01.01.49.S.B.nyarsavarp.pdf

Black, William K. (2005), The Best Way to Rob a Bank Is to Own One: How Corporate Executives and Politicians Looted the S\&L Industry, University of Texas Press, Austin. Charlton, Roger (1986), Political Realities: Comparative Government Longman, London. Elkins, Zachary, Tom Ginsburg, and James Melton (2012), “A Review of Iceland's Draft Constitution," <http://comparativeconstitutionsproject.org/wp-content/uploads/CCP-IcelandReport.pdf> as accessed on January 26, 2016.

Elster, Jon (1995), "Forces and Mechanisms in the Constitution-Making Process," Duke Law Journal 45, 364-396.

Ferguson, Charles H. (2012), Predator Nation: Corporate Criminals, Political Corruption, and the Hijacking of America, Random House, New York.

Gallup (2013), "Government Corruption Viewed as Pervasive Worldwide” by Jan Sonnenschein and Julie Ray. Accessed 9 April 2016. http://www.gallup.com/poll/165476/governmentcorruption-viewed-pervasive-worldwide.aspx

Gunnarsson, Styrmir (2009), Umsátrið (The Siege), Veröld, Reykjavík.

Gylfason, Thorvaldur (2010), “Iceland's Special Investigation: The Plot Thickens,” VoxEU, 30 April.

Gylfason, Thorvaldur (2012), “Constitution Making in Action: The Case of Iceland,” VoxEU, 1 November.

Gylfason, Thorvaldur (2013), "From Collapse to Constitution: The Case of Iceland," in Public Debt, Global Governance and Economic Dynamism, edited by Luigi Paganetto, 379-417, Springer, Berlin.

Gylfason, Thorvaldur (2015a), "Iceland: How Could This Happen?" in Reform Capacity and Macroeconomic Performance in the Nordic Countries, edited by Torben M. Andersen, 
Michael Bergman, and Svend E. Hougaard Jensen, Oxford University Press, Oxford and New York.

Gylfason, Thorvaldur (2015b), "Social Capital, Inequality, and Economic Crisis," Challenge 58, No. 4, July, 326-342.

Gylfason, Thorvaldur (2016), “Constitution on Ice,” in Iceland's Financial Crisis: The Politics of Blame, Protest, and Reconstruction, edited by Valur Ingimundarson, Philippe Urlfalino, and Irma Erlingsdóttir, Routledge, June.

Gylfason, Thorvaldur, Bengt Holmström, Sixten Korkman, Hans Tson Söderström, and Vesa Vihriala (2010), Nordics in Global Crisis, Research Institute of the Finnish Economy (ETLA), Taloustieto Oy.

Gylfason, Thorvaldur, and Anne Meuwese (2016), "Digital Tools and the Derailment of Iceland's New Constitution," CESifo Working Paper, forthcoming.

Helgason, Thorkell (2011), “Greining á úrslitum kosningar til stjórnlagapings 27. nóvember 2010" (Analysis of the results of the Constitutional Assembly election 27 November 2010), Icelandic Review of Politics and Administration 7, No. 1.

Jónsson, Halldór (1990), “Ákvarðanataka í sjávarútvegi og stjórnun fiskveiða” (Decision making in the Fishing Industry and Fisheries Management), Samfélagstíðindi (Social Science Bulletin) $10,99-141$.

Kristjánsson, Svanur (2011), “Varð pjóðpingið að pjófpingi? Lýðræðið og kvótakerfið 1983” (Did Parliament Become Kleptocratic? Democracy and the Quota System 1983), Skírnir, Fall, 261-290.

Meuwese, Anne C. M. (2013), "Popular Constitution-making. The Case of Iceland," in The Social and Political Foundations of Constitutions, edited by D. Galligan and M. Versteeg, Cambridge University Press, New York.

Special Investigation Commission (SIC), 2010, "Report of the Special Investigation Commission (SIC)," delivered to Althingi, the Icelandic Parliament, April 12. Accessed August 17, 2014. http://www.rna.is/eldri-nefndir/addragandi-og-orsakir-falls-islensku-bankanna-2008/skyrsla$\underline{\text { nefndarinnar/english/ }}$

Thorláksson, Indridi H. (2015), "Veiðigjöld 2015. Annar hluti” (Fishing Fees 2015. Part Two).

O‘Toole, Flintan (2010), Ship of Fools: How Stupidity and Corruption Sank the Celtic Tiger, PublicAffairs. Dublin. 
Wade, Robert (2009), “Iceland as Icarus,” Challenge 52, No. 3, May/June, 5-33.

Wenar, Leif (2016), Blood Oil: Tyrants, Violence, and the Rules that Run the World, Oxford University Press, Oxford and New York.

Willmann, Rolf, and Kieran Kelleher (2009), The Sunken Billions: The Economic Justification for Fisheries Reform, World Bank, Washington, D.C.

World Values Survey (2014), “Interpersonal Trust.” Accessed September 23, 2014.

http://www.jdsurvey.net/jds/jdsurveyMaps.jsp?Idioma=I\&SeccionTexto=0404\&NOID=104 